\title{
Evaluasi Kesuksesan Portal Online Dengan Pendekatan Model DeLone Dan McLean (Studi Kasus: Perusahaan XYZ)
}

\author{
Rizqina Gardenta Maranaisya ${ }^{1}$, Dien Novita ${ }^{2}$ \\ ${ }^{1,2}$ STMIK GI MDP; Jl. Rajawali No.14, Telp: (0711)376400 \\ ${ }^{1,2}$ Jurusan Sistem Informasi, STMIK GI MDP, Palembang \\ e-mail: ${ }^{1}$ rizqinagardenta@gmail.com, ${ }^{2}$ dien@mdp.ac.id
}

\begin{abstract}
Abstrak
Perusahaan XYZ telah memanfaatkan sistem informasi untuk tetap bertahan dan berkembang menyesuaikan perkembangan zaman dan arah bisnis yang ada pada saat ini, salah satunya adalah portal online,besarnya peran portal online ini dan belum adanya pengukuran apakah informasi, sistem, dan pelayanan yang ada sudah cukup berkualitas, sehingga peneliti melakukan evaluasi kesuksesan pada portal online perusahaan ini dengan menggunakan pendekatan Model DeLone dan McLean. Untuk mengukur pengaruh antar variabel yang ada, peneliti menggunakan enam variabel yang ada pada model DeLone, yakni kualitas informasi, kualitas sistem, kualitas pelayanan, kepuasan pengguna, penggunaan, dan manfaat-manfaat bersih. Pengolahan data-data statistik diolah menggunakansoftware pengolah data statistik yaitu SmartPLS.Adapun hasil dari penelitian ini adalah kualitas informasi tidak berpengaruh terhadap kepuasan pengguna tetapi kualitas informasi berpengaruh terhadap variabel penggunaan, kualitas pelayanan berpengaruh terhadap kepuasan pengguna tetapi tidak memiliki pengaruh terhadap penggunaan dari suatu sistem, kualitas sistem memiliki pegaruh terhadap penggunaan dan juga variabel kepuasan pengguna, variabel kepuasan pengguna tidak berpengaruh terhadap manfaat-manfaat bersih, kepuasan pengguna tidak berpengaruh terhadap penggunaan, penggunaan tidak berpengaruh terhadap manfaat-manfaat bersih, penggunaan berpengaruh terhadap kepuasan pengguna, manfaat-manfaat bersih tidak berpengaruh terhadap penggunaan dan kepuasan pengguna.
\end{abstract}

Kata kunci-evaluasi, kesuksesan, DeLone dan McLean, statistik, SmartPLS

\section{Abstract}

$X Y Z$ company has used the information system to survive and develop to adjust the times and business direction that exists at this time, one of which is the online portal, the total role of portal online is large and there is no measurement of whether the information, systems, and services are sufficient quality, so the author is interested in evaluating the success of the online portal by using the DeLone and McLean model approach. To measure the influence between existing variables, in this study the author uses six variables in the DeLone model, namely information quality, quality system, quality of service, user satisfaction, usage, and net benefits, where processing of statistical data is processed using SmartPLS statistical data processing software, while the results of this study are quality of information does not affect user satisfaction but the quality of information affects the use variable, service quality affects user satisfaction but does not have an influence on the use of a system, system quality has an influence on usage and also user satisfaction variables, user satisfaction variables have no effect on benefits net benefits, user satisfaction does not affect usage, use does not affect 
netbenefits, usage has an effect on user satisfaction, net benefits have no effect on user use and satisfaction.

Keywords — evaluate, success, DeLone and McLean, statistical, SmartPLS

\section{PENDAHULUAN}

$P^{\mathrm{en}}$ rkembangan teknologi dewasa ini berkembang begitu pesat. Teknologi informasi dan komputer sudah bukan lagi hal yang asing di masyarakat. Sistem Informasi telah bertransformasi dari yang awalnya hanya sebagai penunjang menjadi strategi dalam kegiatan bisnis perusahaan. Dengan adanya sistem informasi beberapa pekerjaan menjadi lebih mudah dan dapat dengan cepat terselesaikan. Kita dapat memberi, mengolah, atau bahkan mendapatkan informasi lebih cepat dan akurat, komunikasi antar belahan dunia kini dapat dengan mudah dilakukan, pengelolaan serta pengolahan data dalam jumlah yang banyak menjadi lebih mudah dan cepat. Contohnya adalah pengolahan data perusahaan yang lingkupnya cukup besar.

Salah satu perusahaan yang sudah menggunakan sistem informasi dalam menunjang setiap kegiatan atau proses bisnis yang berjalan adalah Perusahaan XYZ. Perusahaan tersebut bergerak di bidang logistik dan pangan.

Hal-hal yang melatarbelakangi penelitian di perusahaan XYZ ini adalah telah dimanfaatkannya sistem informasi portal online sebagai penunjang proses bisnis yang sedang berjalan melalui jaringan secara lokal. Sistem informasi tersebut sangat berpengaruh dalam kegiatan operasional, dengan demikian maka perlu dilakukan evaluasi kesuksesan portal online untuk membantu perusahaan mengetahui apakah informasi dan pelayanan yang dihasilkan sudah dapat dikatakan berkualitas dan mampu memberi pengaruh terhadap minat pemakai serta pemakaian portal online itu sendiri dan apakah portal online tersebut sudah dapat dikatakan sebagai sistem yang berkualitas. Sehingga perusahaan dapat mengambil langkah selanjutnya terhadap sistem informasi tersebut.

Untuk melakukan penelitian tersebut peneliti mengacu pada model kesuksesan Delone dan Mclean (2003) Gambar 1. Model DeLone dan Mclean ini sudah banyak digunakan dalam berbagai penelitian karena model ini sudah cukup parsimony, parsimony yakni sederhana tetapi dianggap sudah cukup valid, pada model kesuksesan Model DeLone dan Mclean (2003) terdapat beberapa konstruk/variabel yang digunakan, antara lain adalah variabel kualitas informasi (information quality) yang digunakan untuk mengukur kualitas dari keluaran/output dari suatu sistem informasi, variabel kualitas sistem (system quality) yang digunakan untuk mengukur kualitas dari sistem informasi teknologi tersebut, variabel kualitas pelayanan (service quality) yang digunakan untuk mengukur kualitas dari output maupun proses yang dihasilkan oleh teknologi informasi, variabel penggunaan (intention to use/use) digunakan dalam mengukur tingkat kesediaan meggunakan teknologi sistem informasi, variabel kepuasan pengguna (user satisfaction) yang digunakan untuk mengukur respon dari pengguna sistem informasi pasca penggunaan, dan variabel/konstruk manfaat-manfaat bersih (net benefits) yang digunakan untuk mengukur seberapa besar dampak/manfaat yang dihasilkan oleh sistem informasi baik bagi pemakai individual ataupun organisasi. 


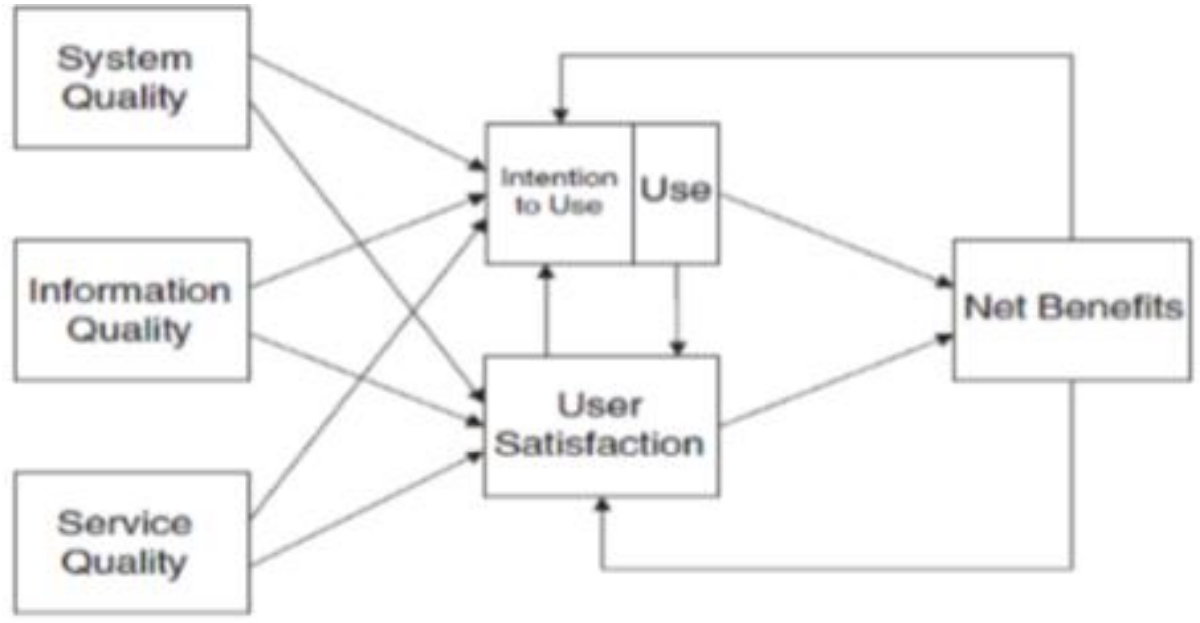

Gambar 1. Model DeLone dan McLean [1]

\section{TINJAUAN PUSTAKA}

\subsection{Metode Pengumpulan Data}

2.1.1 Wawancara (Interview)

Wawancara adalah metode pengumpulan data yang digunakan apabila peneliti ingin melakukan studi pendahuluan untuk menemukan permasalahan yang harus diteliti, dan juga apabila peneliti ingin mengetahui hal-hal dari responden yang lebih mendalam dan jumlah respondennya sedikit/kecil [2].

\subsubsection{Observasi}

Observasi sebagai teknik pengumpulan data mempunyai ciri yang spesifik bila dibandingkan dengan teknik yang lain, yaitu wawancara dan kuesioner. Jika wawancara dan kuesioner selalu berkomunikasi dengan orang, maka observasi tidak terbatas pada orang, tetapi juga pada obyek-obyek alam yang lain juga [2].

\subsubsection{Kuesioner}

Kuesioner merupakan teknik pengumpulan data yang dilakukan dengan cara memberi seperangkat pertanyaan atau pernyataan tertulis kepada responden untuk dijawab. Kuesioner merupakan teknik pengumpulan data yang efisien bila peneliti tahu dengan pasti variabel yang akan diukur dan tahu apa yang diharapkan dari responden. Selain itu kuesioner juga sangat cocok untuk digunakan jika jumlah responden cukup besar dan tersebar di wilayah yang luas.

\subsection{Metode Pengolahan Data}

\subsubsection{Pengujian Outer Model}

Pengukuran outer model dapat menggunakan empat pengujian. Yang pertama, Convergent Validity bertujuan untuk mengukur validitas indikator refleksif sebagai pengukur variabel yang dapat dilihat dari outer loading dari masing-masing indikator variabel. Dan yang kedua adalah Discriminant Validity Latent Variable Correlations bertujuan untuk mengukur nilai korelasi indicator terhadap konstruknya sendiri lebih besar dibandingkan dengan nilai korelasi pada variable laten lainnya. Yang ketiga adalah pengujian AVE (Average Variance Extracted) bertujuan untuk mengukur apakah nilai AVE disetiap konstruk sudah memenuhi

Gardenta et.al \{Evaluasi Kesuksesan Portal Online Dengan Pendekatan Model DeLone dan McLean (Studi Kasus: Perusahaan XYZ)) 
kriteria. Dan yang terakhir adalah pengujian Composite Reliability dan Cronbach Alpha bertujuan untuk mengukur reliabilitas setiap konstruk.

\section{A. Uji Convergent Validity}

Pada uji outer model ini dilakukan uji indikator reflektif dengan convergent validity, dengan kriteria nilai loading factor 0,5 sampai 0,6 sudah dianggap cukup untuk memenuhi kriteria dan indikator individu dianggap reliable [3].

\section{B. Uji Discriminant Validity}

Uji discriminant validity dilakukan untuk mengukur nilai korelasi Cross Loading dengan variabel latennya, dimana nilai tersebut harus lebih besar dibandingkan dengan korelasi terhadap variabel laten yang lain [3].

C. Average Variance Extracted (AVE)

AVE ini dilakukan dengan membandingkan nilai square root of average variance extracted atau akar kuadrat dari AVE (average variance extracted) untuk setiap konstruk dengan korelasi antara konstruk dengan konstruk lainnya dalam model. Nilai AVE masingmasing konstruk harus lebih besar dari 0,5 [3].

D. Composite Reliability dan Cronbach Alpha

Pada uji validitas, dilakukan juga uji reliabilitas konstruk yang diukur dengan dua kriteria, yaitu composite reliability dan cronbach alpha dari indikator yang mengukur konstruk. Konstruk yang reliabel jika nilai composite reliability maupun cronbach alpha diatas 0,7 [3].

\subsubsection{Pengujian Inner Model}

Pengujian inner model dilakukan dengan melihat nilai $\mathrm{R}^{2}$ yang merupakan uji goodnessfit model, dimana digunakan untuk menguji pengaruh antara satu variabel laten dengan variabel laten lainnya baik eksogen maupun endogen.

\section{A. $R^{2}$ untuk Variabel Laten Endogen}

Untuk uji $\mathrm{R}^{2}$ variabel laten endogen mengidentifikasikan bahwa hasil $\mathrm{R}^{2}$ sebesar 0,67 , 0,33 dan 0,19 untuk variabel laten endogen dalam model struktural mengidentifikasi bahwa model tersebut "baik", "moderat", dan "lemah" [3].

B. Koefisien Parameter (Path Coefficient) dan T-Statistik (T-Value)

Pada level signifikansi sebesar 0,05 suatu hipotesis akan diterima bila memiliki t-value lebih besar dari t tabel [3].

\subsection{Partial Least Square}

Partial Least Square (PLS) merupakan pendekatan alternative yang berbasis varian, lebih bersifat predictive model. Dalam permodelan dengan tujuan prediksi memiliki konsekuensi bahwa pengujian dapat dilakukan tanpa dasar teori yang kuat, mengabaikan beberapa asumsi dan parameter ketetepan model prediksi dilihat dari nilai koefisien determinasi [4].

\section{METODE PENELITIAN}

\subsection{Tahapan Penelitian}

Tahapan penelitian yang dilakukan dalam penelitian yaitu peneliti mengawali dengan observasi secara langsung diperusahaan XYZ tepatnya di bagian IT Support, untuk melakukan identifikasi dan menemukan masalah yang ada pada portal online, kemudian dilanjutkan dengan mengindentifikasi populasi, dalam hal ini merupakan pengguna portal online dan mengindentifikasi sampel untuk digunakan dalam penelitian. Setelah mengindentifikasi masalah, populasi, dan sampel, kemudian peneliti melanjutkan penyusunan kuisioner penelitian dan disebarkan ke pengguna portal online di perusahaan XYZ. Setelah melakukan penyebaran kuisioner, peneliti kemudian merekap data hasil dari pengisian kuisioner yang di bagikan untuk 
kemudian dilakukan pengujian atau validasi, reabilitias kuisioner, sehingga dapat dilakukan pengolahan dari hasil kuisioner tersebut. Setelah dilakukan pengelolaan data kuesioner, peneliti menganalisis hasil perhitungan, dilanjutkan dengan penentuan kesuksesan sistem. Setelah semua pengujian selesai, peneliti menarik kesimpulan dari hasil penelitian dan mereporting hasil dari pengujian yang dilakukan. Tahapan penelitian dalam penelitian ini dirangkum seperti Gambar 1 berikut:

\subsection{Subjek Penelitian}

Subjek pada penelitian ini yaitu portal online pada perusahaan XYZ. Sedangkan objek dari penelitian ini adalah staff dan karyawan, serta pihak-pihak yang terlibat langsung dalam penggunaan portal onlinedi Perusahaan XYZ.

\subsection{Variabel dan Indikator}

Dalam penelitian ini terdapat enam variabel yang akan digunakan dengan indikatornya pada Tabel 1.

Tabel 1. Variabel dan Indikator [5]

\begin{tabular}{|c|c|c|c|}
\hline No. & Variabel & Indikator & Sumber \\
\hline \multirow{6}{*}{1.} & \multirow{6}{*}{$\begin{array}{l}\text { Kualitas } \\
\text { Sistem (KS) }\end{array}$} & Keluwesan Sistem (System Flexibelity) & \multirow{6}{*}{ J. Livary (2005) } \\
\hline & & Integrasi Sistem (System integration) & \\
\hline & & Waktu Respon (Time to respond) & \\
\hline & & $\begin{array}{l}\text { Penanggulangan Masalah (Error } \\
\text { recovery) }\end{array}$ & \\
\hline & & $\begin{array}{l}\text { Kenyamanan dalam Mengakses } \\
\text { (Convinience of access) }\end{array}$ & \\
\hline & & Bahasa (Language) & \\
\hline \multirow{8}{*}{2.} & \multirow{7}{*}{$\begin{array}{c}\text { Kualitas } \\
\text { Informasi (KI) }\end{array}$} & Akurasi (Accuracy) & \multirow{8}{*}{$\begin{array}{l}\text { DeLone and } \\
\text { McLean (2003) }\end{array}$} \\
\hline & & Kelengkapan (Completeness) & \\
\hline & & Ketepatwaktuan (Timeliness) & \\
\hline & & Keandalan (Reliability) & \\
\hline & & Ketepatan (Precision) & \\
\hline & & Relevan (Relevance) & \\
\hline & & Kekinian (Currency) & \\
\hline & & Terbarukan (Up to date) & \\
\hline \multirow{3}{*}{3.} & \multirow{3}{*}{$\begin{array}{l}\text { Kualitas } \\
\text { Pelayanan } \\
\text { (KP) }\end{array}$} & Jaminan Keamanan (Assurance) & \multirow{3}{*}{$\begin{array}{l}\text { DeLone and } \\
\text { McLean (2003) }\end{array}$} \\
\hline & & Kepedulian (Empathy) & \\
\hline & & Respon (Responsiveness) & \\
\hline 4. & $\begin{array}{c}\text { Kepuasan } \\
\text { Pengguna } \\
\text { (KPG) }\end{array}$ & Kepuasan Pemakai & Bruwer (1984) \\
\hline 5. & $\begin{array}{l}\text { Penggunaan } \\
\text { (PG) }\end{array}$ & Penggunaan harian (Daily Use Time) & Culnan (1983) \\
\hline \multirow{5}{*}{6.} & \multirow{5}{*}{$\begin{array}{c}\text { Manfaat } \\
\text { Bersih (MB) }\end{array}$} & $\begin{array}{l}\text { Waktu Penyelesaian Tugas (Speed of } \\
\text { Accomplishing task) }\end{array}$ & \multirow{5}{*}{ Davis (1989) } \\
\hline & & Performa Pekerja(Job performance) & \\
\hline & & Keefektifan (Effectiveness) & \\
\hline & & Kemudahan Pekerjaan (Ease of job) & \\
\hline & & $\begin{array}{l}\text { Berguna dalam bekerja (Usefullness in } \\
\text { work) }\end{array}$ & \\
\hline
\end{tabular}




\subsection{Populasi dan Sampel}

Berdasarkan data dari perusahaan XYZ, sebanyak 177 orang yang mempunyai akses untuk masuk kedalam portal online. Sehingga peneliti bisa menyatakan populasi dalam penelitian ini sebanyak $177(N=177)$. Dengan menggunakan perhitungan menggunkana metode Slovin dan dengam nilai margin of error $(d)$ sebesar 0,05 , maka didapat ukuran sampel sebagai berikut:

$$
\begin{gathered}
n=\frac{\mathrm{N}}{\mathrm{N} \cdot \mathrm{d}^{2}+1} \\
n=\frac{177}{1770,05^{2}+1} \\
n=\frac{177}{1,4425} \\
n=122,703 \ldots
\end{gathered}
$$

Sehingga dengan metode Slovin, peneliti mendapatkan angka 123 untuk minimal ukuran sampel penelitian.

\subsection{Teknik Pengolahan Data}

Alat analisis yang digunakan dalam mengolah data untuk menguji hipotesis yang digunakan adalah SEM (Structural Equation Model) yang dioperasikan melalui software SmartPLS.

\subsection{Uji Model}

\section{HASIL DAN PEMBAHASAN} model.

Uji model yang dilakukan dalam penelitian ini ada 2, yaitu uji outer model dan uji inner

\subsubsection{Uji Outer Model}

A. Uji Convergent Validity

Tabel 2 berikut menunjukkan hasil dari uji Convergent Validity setelah dilakukan pengolahan data menggunakan SmartPls.

Tabel 2. Hasil Uji Convergent Validity

\begin{tabular}{|l|r|c|c|c|c|c|}
\hline & \multicolumn{1}{|c|}{ KI } & KP & KPG & KS & MB & PG \\
\hline KI1 & 0,906 & & & & & \\
\hline KI2 & 0,944 & & & & & \\
\hline KI3 & 0,871 & & & & & \\
\hline KI4 & 0,911 & & & & & \\
\hline KI5 & 0,948 & & & & & \\
\hline KI6 & 0,854 & & & & & \\
\hline KI7 & 0,889 & & & & & \\
\hline KI8 & 0,95 & & & & & \\
\hline KP1 & & 0,927 & & & & \\
\hline
\end{tabular}

Gardenta et.al \{Evaluasi Kesuksesan Portal Online Dengan Pendekatan Model DeLone dan McLean (Studi Kasus: 


\begin{tabular}{|l|r|r|r|r|r|r|} 
KP2 & & 0,932 & & & & \\
\hline KP3 & & 0,748 & & & & \\
\hline KPG1 & & & 1 & & & \\
\hline KS1 & & & & 0,74 & & \\
\hline KS2 & & & & 0,768 & & \\
\hline KS3 & & & & 0,734 & & \\
\hline KS4 & & & & 0,719 & & \\
\hline KS5 & & & & 0,716 & & \\
\hline KS6 & & & & 0,744 & & \\
\hline MB1 & & & & & 0,932 & \\
\hline MB2 & & & & & 0,914 & \\
\hline MB3 & & & & & 0,897 & \\
\hline MB4 & & & & & 0,92 & \\
\hline MB5 & & & & & 0,85 & \\
\hline PG1 & & & & & & 1 \\
\hline
\end{tabular}

Sumber: Data yang diolah, 2018

Dari hasil pengujian diatas terlihat bahwa nilai indikator loading factor Keluwesan Sistem (KS1) sebesar 0,740, Integrasi Sistem (KS2) sebesar 0,768, Waktu Respon (KS3) sebesar 0,734, Penanggulangan Masalah (KS4) sebesar 0,719, Kenyamanan dalam Mengakses (KS5) sebesar 0,716. Bahasa (KS6) sebesar 0,744 terhadap Kualitas Sistem (KS) masingmasing berada diatas 0,70. Hal ini membuktikan bahwa masing-masing konstruk mampu menjelaskan variabel Kualitas Sistem.

Kualitas Informasi (KI) memiliki nilai indikator loading factor Akurasi (KI1) sebesar 0,906, Kelengkapan (KI2) sebesar 0,944, Ketepatwaktuaan (KI3) sebesar 0.871, Keandalan (KI4) sebesar 0,911, Ketepatan (KI5) sebesar 0,948, Relevan (KI6) sebesar 0,854. Kekinian (KI7) sebesar 0,889. Terbarukan (KI8) sebesar 0,950 sehingga hal ini dapat menggambarkan bahwa masing-masing konstruk mampu menjelaskan variabel Kualitas Informasi (KI).

Kualitas Pelayanan (KP) memiliki nilai indikator loading factor Jaminan Keamanan (KP1) sebesar 0,927, Kepedulian (KP2) sebesar 0,932, dan Responsivitas (KP3) sebesar 0,748. Hal ini membuktikan bahwa masing-masing konstruk mampu menjelaskan variabel Kualitas Pelayanan karena hasil loading factor berada diatas 0,70 .

Kepuasan Pengguna (KPG) merupakan variabel intervening, yang memiliki nilai indikator loading factor Kepuasan Pengguna (KPG1) sebesar 1.000. Hal ini menujukkan bahwa konstruk mampu menjelaskan variabel Kepuasan Pengguna (KPG).

Penggunaan (PG) memiliki nilai indikator loading factor Pengunaan (PG1) sebesar 1.000, Hal ini menujukkan bahwa konstruk mampu menjelaskan variabel Kepuasan Pengguna (KPG).

Manfaat-manfaat Bersih (MB) memiliki nilai indikator loading factor Waktu Penyelesaian Tugas (MB1) sebesar 0,932, Performa Pekerjaan (MB2) sebesar 0,914, Keefektifan (MB3) sebesar 0,897, Kemudahan Pekerjaan (MB4) sebesar 0,920, Berguna dalam Bekerja (MB5) sebesar 0,850. Hal ini membuktikan bahwa masing-masing konstruk mampu menjelaskan variabel manfaat-manfaat bersih karena hasil loading factor berada diatas 0,70.

B. Uji Discriminant Validity

Berikut Tabel 3 merupakan tabel dari hasil pengujian Discriminant Validity Latent Variable Correlations. 
Tabel 3. Hasil Uji Discriminant Validity

\begin{tabular}{|l|r|r|r|r|r|r|}
\hline & \multicolumn{1}{l|}{ KI } & \multicolumn{1}{l|}{ KP } & \multicolumn{1}{l|}{ KPG } & \multicolumn{1}{l|}{ KS } & \multicolumn{1}{l|}{ MB } & \multicolumn{1}{l|}{ PG } \\
\hline KI & 1 & 0.163 & 0.323 & 0.37 & -0.039 & 0.481 \\
\hline KP & 0.163 & 1 & 0.646 & 0.577 & 0.172 & 0.372 \\
\hline KPG & 0.323 & 0.646 & 1 & 0.741 & 0.217 & 0.49 \\
\hline KS & 0.37 & 0.577 & 0.741 & 1 & 0.276 & 0.72 \\
\hline MB & -0.039 & 0.172 & 0.217 & 0.276 & 1 & 0.165 \\
\hline PG & 0.481 & 0.372 & 0.49 & 0.72 & 0.165 & 1 \\
\hline
\end{tabular}

Sumber: Data yang diolah, 2018

Dari tabel diatas terlihat bahwa nilai korelasi indikator terhadap konstruknya sendiri lebih besar dibandingkan dengan korelasi antara indikator dengan konstruk lainnya, sehingga dapat disimpulkan bahwa konstruk dalam penelitian ini memiliki Discriminant Validity yang tinggi.

C. Uji Average Varians Extracted

Berikut tabel 4 merupakan tabel hasil pengujian Average Varians Extracted.

Tabel 4. Hasil Uji Average Varians Extracted

\begin{tabular}{|l|l|l|}
\hline & AVE & $\sqrt{ }$ AVE \\
\hline KI & 0,828 & 0,909945 \\
\hline KP & 0,762 & 0,87292 \\
\hline KPG & 1 & 1 \\
\hline KS & 0,543 & 0,73075 \\
\hline MB & 0,815 & 0,90277 \\
\hline PG & 1 & 1 \\
\hline
\end{tabular}

Sumber: Data yang diolah, 2018

Dari tabel 4 dapat dilihat bahwa indikator KI,KP,KPG,KS,MB, dan PG memiliki nilai lebih besar dari 0,50. Pada tabel 4 juga dapat dilihat bahwa nilai $\sqrt{ }$ AVE masing-masing variabel lebih besar dibandingkan dengan korelasi antara variabel lainnya.

D. Uji Composite Reliability Alpha.

Berikut ini tabel 5 merupakan tabel hasil pengujian Composite Reliability dan Cronbach

Tabel 5. Hasil Uji Composite Reliability dan Cronbach's Alpha

\begin{tabular}{|l|l|l|}
\hline & $\begin{array}{l}\text { Cronbach's } \\
\text { Alpha }\end{array}$ & CompositeReliability \\
\hline KI & 0,97 & 0,975 \\
\hline KP & 0,838 & 0,905 \\
\hline KPG & 1 & 1 \\
\hline KS & 0,859 & 0,877 \\
\hline MB & 0,946 & 0,957 \\
\hline PG & 1 & 1 \\
\hline
\end{tabular}

Sumber: Data yang diolah, 2018

Gardenta et.al \{Evaluasi Kesuksesan Portal Online Dengan Pendekatan Model DeLone dan McLean (Studi Kasus: Perusahaan XYZ)) 
Dari data tabel diatas menunjukkan bahwa seluruh konstruk memiliki nilai Cronbach's Alpha diatas 0,70 dan untuk hasil uji Composite Reliability juga memiliki nilai diatas 0,70. Hal ini membuktikan bahwa nilai reliabilitas semua indikator dalam model sudah ideal dan tidak ditemukan adanya masalah pada model yang dibentuk sehingga model dapat dipergunakan untuk menguji hipotesis selanjutnya.

\subsubsection{Uji Inner Model}

A. $U j i R^{2}$

Berikut adalah Tabel 6 merupakan tabel hasil pengujian $\mathrm{R}^{2}$ untuk variabel laten endogen.

Tabel 6. Hasil Uji $\mathrm{R}^{2}$ untuk Variabel Laten Endogen

\begin{tabular}{|l|l|l|l|}
\hline & $\mathrm{R}^{2}$ & Persentase & Keterangan \\
\hline KPG & 0,626 & $62,6 \%$ & Moderat \\
\hline MB & 0,052 & $5,20 \%$ & Lemah \\
\hline PG & 0,579 & $57,9 \%$ & Moderat \\
\hline
\end{tabular}

Sumber: Data yang diolah, 2018

Dari Tabel 6dapat dilihat bahwa variabel KPG memiliki nilai $\mathrm{R}^{2}$ sebesar 0,626 atau $62,6 \%$ termasuk dalam kategori moderat. Variabel MB memiliki nilai $\mathrm{R}^{2}$ sebersar 0,052 atau $5,20 \%$ termasuk dalam kategori lemah. Sedangkan variabel PS memiliki nilai $\mathrm{R}^{2}$ sebesar 0,583 atau $58,3 \%$ termasuk dalam kategori moderat.

B. Uji T-statistik

Berikut adalah Tabel 7 merupakan Output Path Coefficientshasil dari Uji T-Statistik.

Tabel 7. Hasil Output Path Coefficients

\begin{tabular}{|l|c|c|l|}
\hline & $\begin{array}{c}\text { Sampel } \\
\text { Asli (O) }\end{array}$ & T Stat $(|\mathrm{O} / \mathrm{STDEV}|)$ & \multicolumn{1}{|c|}{ Keterangan } \\
\hline KI -> KPG & 0,076 & 1,618 & Tidak berpengaruh \\
\hline KI -> PG & 0,255 & 4,212 & Berpengaruh \\
\hline KP -> KPG & 0,334 & 3,112 & Berpengaruh \\
\hline KP -> PG & $-0,006$ & 0,065 & Tidak berpengaruh \\
\hline KPG -> MB & 0,179 & 1,752 & Tidak berpengaruh \\
\hline KPG -> PG & $-0,122$ & 1,304 & Tidak berpengaruh \\
\hline KS -> KPG & 0,52 & 5,638 & Berpengaruh \\
\hline KS -> PG & 0,72 & 8,217 & Berpengaruh \\
\hline PG -> MB & 0,077 & 0,749 & Tidak berpengaruh \\
\hline PG -> KPG & 0,467 & 5,07 & Berpengaruh \\
\hline MB -> KPG & 0,14 & 1,856 & Tidak berpengaruh \\
\hline MB -> PG & 0,165 & 1,935 & Tidak berpengaruh \\
\hline
\end{tabular}

Sumber: Data yang diolah, 2018

Hasil output Path Coefficients untuk Uji T-Statistik di Tabel 7 menunjukkan hanya hipotesis $\mathrm{KI}$-> PG, KP -> KPG, KS -> KPG, KS -> PG, dan PG -> KPG yang diterima, karena

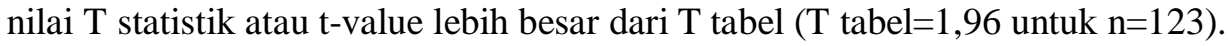


Berdasarkan hasil uji T-statistik untuk pengujian hipotesis tersebut, diperoleh hasil dari pengujian untuk penelitian ini berdasarkan model DeLone dan McLean adalah seperti Gambar 2.

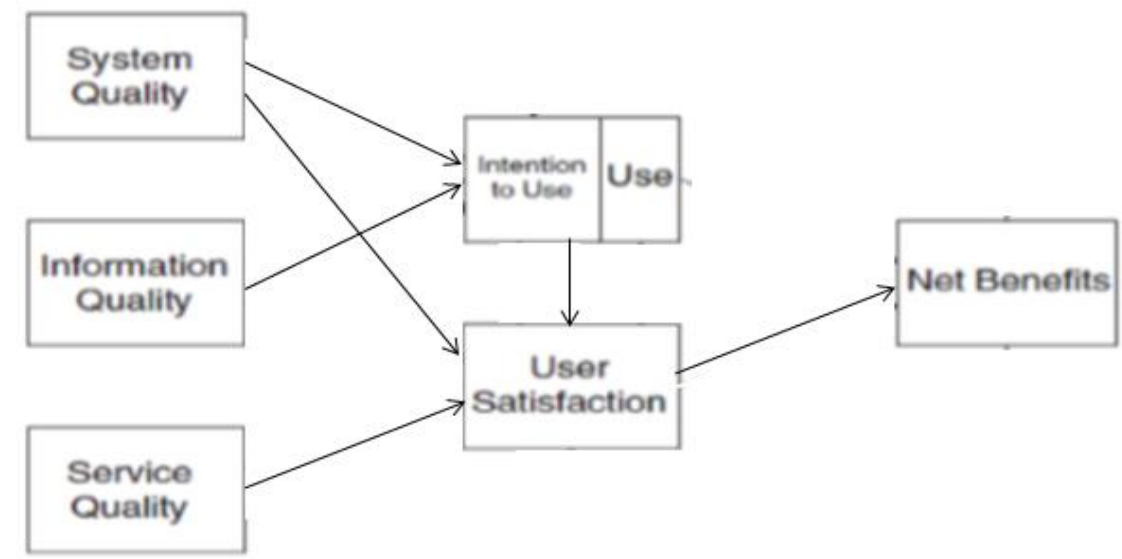

Gambar 2. Hasil Pengujian Hipotesis

Berdasarkan hasil pengujian hipotesis yang diperoleh dari penelitian ini, jika mengacu dari model kesuksesan DeLone dan McLean, menunjukkan bahwa informasi dan pelayanan yang dihasilkan oleh sistem informasi portal online perusahaan XYZ tersebut tidak sepenuhnya berkualitas dan mampu memberi pengaruh terhadap minat pemakai serta pemakaian portal online itu sendiri dan portal online tersebut belum dapat dikatakan sebagai sistem yang memenuhi kriteria kesuksesan suatu sistem informasi.

\section{KESIMPULAN DAN SARAN}

\subsection{Kesimpulan}

Kesimpulan dari penelitian Evaluasi Kesuksesan Portal Online dengan Pendekatan Model DeLone dan McLean (Studi Kasus: Perusahaan XYZ), antara lain:

1. Kualitas informasi tidak memiliki pengaruh terhadap kepuasan pengguna. Hal tersebut menunjukkan bahwa kepuasan pengguna dalam menggunakan portal online tidak bergantung pada kualitas informasi yang diwakili oleh indikator dari kualitas informasi yang digunakan yakni akurasi, kelengkapan, ketepatwaktuan, keandalan, ketepatan, relevan, kekinian, dan terbarukan, pengguna mempunyai indikator yang lain yang tidak digunakan dalam penelitian ini dalam menentukan dan menemukan kepuasan penggunaan dari suatu sistem.

2. Kualitas informasi memiliki pengaruh terhadap penggunaan. Hal tersebut menunjukkan bahwa kualitas informasi merupakan hal yang berpengaruh terhadap penggunaan sistem, yang jika diterapkan pada portal online, kualitas suatu informasi ini dinilai menjadi tolak ukur pengguna untuk menggunakan sistem tersebut.

3. Kualitas pelayanan memiliki pengaruh terhadap kepuasan pengguna, hal ini menunjukkan bahwa kualitas pelayanan yang baik memberikan pengaruh terhadap kepuasan penggunaan sebuah sistem, artinya dengan baiknya kualitas pelayanan yang diberikan suatu sistem akan sangat berpengaruh terhadap puas atau tidaknya pengguna sistem. 
4. Kualitas pelayanan tidak memiliki pengaruh terhadap penggunaan, hal ini menunjukkan bahwa kualitas pelayanan yang baik tidak memberikan pengaruh terhadap penggunaan sebuah sistem.

5. Kepuasan pengguna tidak memiliki pengaruh terhadap manfaat-manfaat bersih, hal ini menunjukkan bahwa kepuasan pengguna tidak memberikan pengaruh terhadap manfaatmanfaat bersih, artinya kepuasan pengguna tidak akan memberikan manfaat-manfaat tertentu untuk organisasi.

6. Kepuasan pengguna tidak memiliki pengaruh terhadap penggunaan, hal ini menunjukkan bahwa kepuasan pengguna tidak memberikan pengaruh terhadap penggunaan, artinya kepuasan pengguna tidak akan mendorong pengguna untuk menggunakan sistem kembali.

7. Kualitas sistem memiliki pengaruh terhadap kepuasan pengguna, hal ini menunjukkan bahwa kualitas sistem yang baik memberikan pengaruh terhadap kepuasan pengguna terhadap sistem, dengan sistem yang berkualitas, pengguna akan merasakan kepuasan dalam menggunakan sistem tersebut.

8. Kualitas sistem memiliki pengaruh terhadap penggunaan, hal ini menunjukkan bahwa kualitas sistem berpengaruh terhadap penggunaan, artinya kualitas sistem yang baik akan membuat seseorang mempunyai minat untuk menggunakan sistem tersebut

9. Penggunaan memiliki pengaruh terhadap kepuasan pengguna, hal ini menunjukkan bahwa penggunaan yang cukup intens memberikan pengaruh terhadap kepuasan pengguna suatu sistem.

10. Penggunaan tidak memiliki pengaruh terhadap manfaat-manfaat bersih, hal ini menunjukkan bahwa suatu penggunaan yang intens tidak memberikan pengaruh secara langsung terhadap manfaat-manfaat bersih yang akan diterima oleh perusahaan XYZ.

11. Manfaat-manfaat bersih tidak memiliki pengaruh terhadap kepuasan pengguna, hal ini menunjukkan bahwa adanya manfaat-manfaat bersih terhadap perusahaan XYZ tidak memiliki pengaruh terhadap kepuasan pengguna.

12. Manfaat-manfaat bersih tidak memiliki pengaruh terhadap penggunaan, hal ini menunjukkan bahwa manfaat-manfaat bersih yang diterima perusahaan XYZ belum dapat mendorong pengguna untuk kembali lagi menggunakan sistem yang ada.

\subsection{Saran}

Berikut beberapa saran dari penelitian Evaluasi Kesuksesan Portal Online dengan

Pendekatan Model DeLone dan McLean (Studi Kasus: Perusahaan XYZ), antara lain:

1. Hasil dari penelitian ini diharapkan dapat memberikan masukan dan menjadi acuan bagi peneliti selanjutnya untuk melakukan penelitian yang sama dengan memanfaatkan beberapa indikator dari sumber yang berbeda untuk hasil yang lebih baik lagi.

2. Dari hasil penelitian penulis mengharapakan akan adanya perbaikan atau penyempurnaan mengenai sistem terkait yaitu portal online perusahaaan XYZ sesuai dengan hasil yang didapatkan.

\section{DAFTAR PUSTAKA}

[1] DeLone, W. H., McLean, E. R. 2003, The DeLone and McLean Model of Information Systems Success: A Ten-Year Update, J. Manag. Inf. Syst. Vol. 19(4): 9-30.

[2] Jogiyanto, HM 2009, Analisis \& Desain, Andi Offset, Yogyakarta. 
[3] Wiyono Gendro. 2011, Merancang Penelitian Bisnis dengan Alat Analisis SPSS 17.0 \& SmartPLS 2.0, UPP STIM YKPN, Yogyakarta.

[4] Siregar Syofian. 2013, Metode Penelitian Kuantitatif Dilengkapi dengan Perbandingan Perhitungan Manual \& SPSS, Prenadamedia Group, Jakarta.

[5] Jogiyanto. 2007, Model Kesuksesan Sistem Teknologi Informasi Andi Offset, Yogyakarta. 